\title{
Nitratireductor aquibiodomus gen. nov., sp. nov., a novel $\alpha$-proteobacterium from the marine denitrification system of the Montreal Biodome (Canada)
}

\author{
Correspondence \\ Richard Villemur \\ richard.villemur@inrs-iaf. \\ uquebec.ca
}

\author{
Normand Labbé, ${ }^{1}$ Serge Parent ${ }^{2}$ and Richard Villemur ${ }^{1}$ \\ ${ }^{1}$ INRS - Institut Armand-Frappier, 531 Boul. des Prairies, Laval, Canada H7V 1B7 \\ ${ }^{2}$ Biodôme de Montréal, 4777 Pierre-De Coubertin, Montreal, Canada H1V 1B3
}

\begin{abstract}
The Montreal Biodome operates a methanol-fed denitrification system that treats the water in its three million litre marine mesocosm. An unknown bacterium, named strain $\mathrm{NL}_{2} 1^{\top}$, was isolated from this system on TSA and R2A agar. The organism is a Gram-negative, rod-shaped $(1 \times 3 \mu \mathrm{m})$ facultative aerobe. Optimal growth conditions on R2A agar are $30-35^{\circ} \mathrm{C}, \mathrm{pH} 7-7.5$ and $1 \%$ $(\mathrm{w} / \mathrm{w}) \mathrm{NaCl}$. Phylogenetic analysis of the $16 \mathrm{~S}$ rDNA sequence reveals that strain NL21 ${ }^{\top}$ forms a novel lineage in the family 'Phyllobacteriaceae' within the $\alpha 2$ subgroup of the Proteobacteria. The closest related genera are Aminobacter, Pseudaminobacter, Mesorhizobium and Defluvibacter. Major cellular fatty acids are $\mathrm{C}_{18: 1} \omega 7 c(75 \%), \mathrm{C}_{19: 0} \omega 8 c$ cyclopropane $(9 \cdot 4 \%)$ and $\mathrm{C}_{18: 0}$ $(4 \cdot 2 \%)$. The DNA G $+\mathrm{C}$ content of strain NL21 ${ }^{\top}(57 \mathrm{~mol} \%)$ differs from those of all other described members of the 'Phyllobacteriaceae' (60-64 mol\%). Strain NL21 ${ }^{\top}$ reduces nitrate to nitrite, but does not reduce nitrite to nitrogen gas. Only a few sugars and amino acids can serve as carbon sources. Strain NL21 ${ }^{\top}$ is able to grow without salt and tolerates up to $5 \% \mathrm{NaCl}$. Phylogenetic analysis, as well as physiological and biochemical tests, showed that strain $\mathrm{NL} 21^{\top}$ was different from all other members of the 'Phyllobacteriaceae' with validly published names. Strain NL21 ${ }^{\top}$ therefore represents a novel genus, for which the name Nitratireductor aquibiodomus gen. nov., sp. nov. is proposed, with the type strain NL21 ${ }^{\top}\left(=\mathrm{DSM} 15645^{\top}=\right.$ ATCC BAA-762 $\left.2^{\top}\right)$.
\end{abstract}

Nitrate is a pollutant that accumulates quickly in closed systems, such as marine aquariums. It is usually removed biologically in a denitrification system, where oxygen is replaced by nitrate as an electron acceptor in bacterial respiration. A large variety of bacterial species are able to reduce nitrate to nitrite or to molecular nitrogen [see Zumft (1997) for an exhaustive list]. Many of these species belong to the family 'Phyllobacteriaceae' of the $\alpha$-Proteobacteria, which comprises the genera Phyllobacterium (Knösel, 1984), Aminobacter (Urakami et al., 1992), Mesorhizobium (Jarvis et al., 1997), Pseudaminobacter (Kämpfer et al., 1999), Defluvibacter (Fritsche et al., 1999) and Aquamicrobium (Bambauer et al., 1998). This family was originally described by Knösel (1984). It may also contain the uncharacterized strain B1G-2, which was isolated by Duncan et al. (2001), and the Mesorhizobium strain WG, which was isolated from a denitrification process by Costa et al. (2000).

Published online ahead of print on 12 September 2003 as DOI 10.1099/ijs.0.02793-0.

The GenBank/EMBL/DDBJ accession number for the 16S rRNA gene sequence of strain $\mathrm{NL}^{\top} 1^{\top}$ is $\mathrm{AF} 534573$.
During the characterization of organisms that were isolated from the marine denitrification system of the Montreal Biodome (Labbé et al., 2003), strain $\mathrm{NL}_{2} 1^{\mathrm{T}}$ was recovered on R2A and TSA agar. Sequence analysis of the 16S rRNA gene (rDNA) revealed that this bacterium was related to the family 'Phyllobacteriaceae'. The goal of the present study was to further characterize strain NL2 $1^{\mathrm{T}}$ and to classify it within the family 'Phyllobacteriaceae'.

Gram-staining was performed as described by Gerhardt et al. (1994). Cell morphology was observed under a Nikon light microscope at $\times 1000$ with cells that were grown for 3 days at $35^{\circ} \mathrm{C}$. Physiological characteristics were investigated by using API systems: API 50CH strips inoculated with the medium described by Velázquez et al. (2001) were used for acid production and sugar assimilation, API 20NE strips were used for biochemical reactions (nitrate and nitrite reduction, urease and indole formation) and the assimilation of selected carbon sources and API ZYM strips were used to examine extracellular enzyme activity. Strips were incubated at $30^{\circ} \mathrm{C}$ for $24 \mathrm{~h}$ (API ZYM) or $72 \mathrm{~h}$ (API $50 \mathrm{CH}$ and API 20NE). Strain $\mathrm{NL} 21^{\mathrm{T}}$ differs from most members of the family 'Phyllobacteriaceae' by being positive 
for citrate assimilation, negative for urease and positive for the presence of $N$-acetyl- $\beta$-glucosamidase (Table 1 ). Other differences in substrate assimilation between $\mathrm{NL}^{2} 1^{\mathrm{T}}$ and other representatives of the family 'Phyllobacteriaceae' are shown in Table 1.

The fatty acid profile was traced with cells that were grown on TSA agar for 3 days at $35^{\circ} \mathrm{C}$. Analysis was carried out in accordance with the standard protocol of the Microbial
Identification system (MIDI; Microbial ID). Major cellular fatty acids of strain $\mathrm{NL}_{2} 1^{\mathrm{T}}$ are $\mathrm{C}_{18: 1} \omega 7 c(75 \%), \mathrm{C}_{19: 0} \omega 8 c$ cyclo $(9 \cdot 4 \%)$ and $\mathrm{C}_{18: 0}(4 \cdot 2 \%)$. This profile supports the affiliation of strain NL21 ${ }^{\mathrm{T}}$ to the 'Phyllobacteriaceae', in which most species have $\mathrm{C}_{18: 1} \omega 7 c$ and $\mathrm{C}_{19: 0} \omega 8 c$ cyclo as major components. The fatty acid profile of strain NL21 ${ }^{\mathrm{T}}$ (Table 2) differs from those of all species of the genus Mesorhizobium (Tighe et al., 2000) because of the absence of 11-methyl $\mathrm{C}_{18: 1} \omega 7 c$. The two genera also have different

Table 1. Physiological characteristics of the family 'Phyllobacteriaceae'

Taxa: 1, strain NL21 ${ }^{\mathrm{T}} ; 2$, Pseudaminobacter salicylatoxidans DSM $6986^{\mathrm{T}} ; 3$, Aminobacter aminovorans DSM $7048^{\mathrm{T}} ; 4$, Phyllobacterium myrsina-

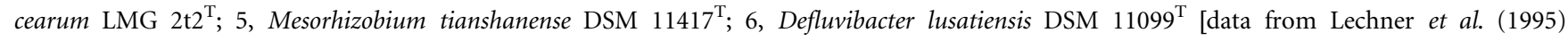
and Fritsche et al. (1999)]. All strains are positive for assimilation of D-glucose, D-arabinose, D-fructose, ribose, D-xylose and L-fucose and the presence of alkaline phosphatase, acid phosphatase, leucine arylamidase, cysteine arylamidase, trypsin, naphthol-AS-BI-phosphohydrolase and $\alpha$-glucosidase. All strains are negative for indole formation, gelatinase, assimilation of caprate, phenylacetate, salicin, inulin, starch and erythritol and the presence of $\alpha$-galactosidase, $\beta$-glucuronidase, $\alpha$-mannosidase, $\alpha$-fucosidase and lipase C14. + , Positive reaction; ( + ), weakly positive reaction; -, negative reaction; $\mathrm{v}$, variable; ND, not determined.

\begin{tabular}{|c|c|c|c|c|c|c|}
\hline Characteristic & 1 & 2 & 3 & 4 & 5 & 6 \\
\hline Major fatty acids* & $\begin{array}{c}\mathrm{C}_{18: 1} \omega 7 c \\
\mathrm{C}_{19: 0} \omega 8 c \text { cyclo, } \\
\mathrm{C}_{18: 0}\end{array}$ & $\begin{array}{c}\mathrm{C}_{18: 1} \omega 7 c \\
\mathrm{C}_{19: 0} \omega 8 c \text { cyclo, } \\
\mathrm{C}_{17: 0}\end{array}$ & $\begin{array}{c}\mathrm{C}_{18: 1} \omega 7 c \\
\mathrm{C}_{19: 0} \omega 8 c \text { cyclo, } \\
\mathrm{C}_{16: 0}\end{array}$ & $\begin{array}{c}\mathrm{C}_{18: 1} \omega 7 c \\
\mathrm{C}_{16: 0}, \\
\mathrm{C}_{16: 0} 3-\mathrm{OH}\end{array}$ & $\begin{array}{c}\mathrm{C}_{18: 1} \omega 7 c, \\
\mathrm{C}_{19: 0} \omega 8 c \text { cyclo, } \\
\mathrm{C}_{16: 0} \dagger\end{array}$ & $\begin{array}{c}\mathrm{C}_{18: 1} \omega 7 c \\
\mathrm{C}_{19: 0} \omega 8 c \text { cyclo, } \\
\mathrm{C}_{16: 0}\end{array}$ \\
\hline Nitrate reduction & + & + & - & - & + & - \\
\hline Nitrite reduction & - & - & - & - & + & - \\
\hline Urease & - & + & + & + & + & - \\
\hline Aesculin & - & - & - & $(+)$ & + & - \\
\hline \multicolumn{7}{|l|}{ Assimilation of: } \\
\hline Adipate & $(+)$ & $(+)$ & $(+)$ & - & - & - \\
\hline Malate & $(+)$ & $(+)$ & - & + & + & $\mathrm{v}$ \\
\hline Citrate & + & - & - & $(+)$ & - & - \\
\hline Sucrose & - & - & + & + & + & - \\
\hline Gluconate & - & - & - & - & + & + \\
\hline Adonitol & - & + & - & + & + & + \\
\hline Trehalose & - & - & + & + & + & - \\
\hline D-Xylose & - & + & + & - & $\mathrm{v}$ & $\mathrm{v}$ \\
\hline Galactose & - & $\mathrm{V}$ & + & $(+)$ & + & - \\
\hline D-Turanose & - & - & + & + & - & - \\
\hline Rhamnose & - & - & + & + & + & - \\
\hline Mannitol & - & + & + & + & + & - \\
\hline Maltose & - & - & + & + & + & - \\
\hline Sorbitol & - & + & + & + & + & ND \\
\hline \multicolumn{7}{|l|}{ Extracellular activity of: } \\
\hline$N$-Acetyl- $\beta$-glucosamidase & + & - & - & - & + & ND \\
\hline Esterase C4 & + & - & + & + & + & ND \\
\hline Esterase lipase C8 & + & - & + & + & + & ND \\
\hline$\beta$-Galactosidase & - & - & - & - & $(+)$ & - \\
\hline$\beta$-Glucosidase & - & - & - & - & + & ND \\
\hline$\alpha$-Chymotrypsin & - & - & - & + & - & ND \\
\hline DNA G $+\mathrm{C}$ content $(\mathrm{mol} \%) \neq$ & 57 & $63 \cdot 9$ & $62 \cdot 5$ & 60 & 61 & $61 \cdot 4$ \\
\hline
\end{tabular}

*Data from Kämpfer et al. (1999) for Pseudaminobacter salicylatoxidans and Aminobacter aminovorans, from Mergaert et al. (2002) for Phyllobacterium myrsinacearum and from Tighe et al. (2000) for Mesorhizobium tianshanense.

$\dagger$ Mean values from eight strains, including the type strain.

‡Data from Kämpfer et al. (1999) for Pseudaminobacter salicylatoxidans, from Urakami et al. (1992) for Aminobacter aminovorans, from Knösel (1984) for Phyllobacterium myrsinacearum and from Chen et al. (1995) for Mesorhizobium tianshanense. 
hydroxy fatty acids. Compared to the genus Pseudaminobacter, strain $\mathrm{NL}_{2} 1^{\mathrm{T}}$ has a lower amount of $\mathrm{C}_{17: 0}$ and $\mathrm{C}_{19: 0} \omega 8 c$ cyclo and a higher amount of $\mathrm{C}_{18: 1} \omega 7 c$.
Compared to the genus Aminobacter, strain $\mathrm{NL} 21^{\mathrm{T}}$ has a higher amount of $\mathrm{C}_{18: 1} \omega 7 c$, fewer unknown fatty acids and different hydroxylated fatty acids (Table 2). Compared

Table 2. Fatty acid profiles of bacteria in the family 'Phyllobacteriaceae'

Taxa: 1, Nitratireductor aquibiodomus $\mathrm{NL}^{2} 1^{\mathrm{T}}$; 2, Pseudaminobacter salicylatoxidans DSM $6986^{\mathrm{T}}$ (data from Kämpfer et al., 1999); 3, Aminobacter aminovorans DSM $7048^{\mathrm{T}}$ (data from Kämpfer et al., 1999); 4, Phyllobacterium myrsinacearum LMG $2 \mathrm{t} 2^{\mathrm{T}}$ (data from Mergaert et al., 2002); 5, Mesorhizobium tianshanense (data from Tighe et al., 2000); 6, Defluvibacter lusatiensis DSM $11099^{\mathrm{T}}$ (data from Lechner et al., 1995).

\begin{tabular}{|c|c|c|c|c|c|c|}
\hline Fatty acid & 1 & 2 & 3 & 4 & $5^{*}$ & 6 \\
\hline \multicolumn{7}{|l|}{ Saturated fatty acids: } \\
\hline $\mathrm{C}_{16: 0}$ & $2 \cdot 16$ & $2 \cdot 3$ & $4 \cdot 9$ & 6 & $12 \cdot 25$ & $4 \cdot 33$ \\
\hline $\mathrm{C}_{17: 0}$ & $1 \cdot 72$ & $9 \cdot 1$ & $0 \cdot 7$ & & $0 \cdot 83$ & $2 \cdot 08$ \\
\hline $\mathrm{C}_{18: 0}$ & $4 \cdot 23$ & $2 \cdot 6$ & $1 \cdot 5$ & $2 \cdot 1$ & $4 \cdot 99$ & $2 \cdot 29$ \\
\hline $\mathrm{C}_{20: 0}$ & & & & $4 \cdot 4$ & & \\
\hline \multicolumn{7}{|l|}{ Unsaturated fatty acids $\uparrow:$} \\
\hline \multicolumn{7}{|l|}{$\mathrm{C}_{15: 1} \omega 8 c$} \\
\hline $\mathrm{C}_{16: 1} \omega 7 c$ & & & & & & $1 \cdot 22$ \\
\hline $\mathrm{C}_{17: 1} \omega 8 c$ & $0 \cdot 59$ & $3 \cdot 4$ & $0 \cdot 7$ & & $0 \cdot 52$ & $2 \cdot 08$ \\
\hline $\mathrm{C}_{17: 1} \omega 6 c$ & $0 \cdot 54$ & $1 \cdot 2$ & & & $0 \cdot 11$ & $1 \cdot 01$ \\
\hline $\mathrm{C}_{18: 1} \omega 7 c \ddagger$ & $75 \cdot 01$ & & & $64 \cdot 9$ & & \\
\hline $\mathrm{C}_{18: 1} \omega 9 c$ & $0 \cdot 61$ & & & & & \\
\hline $\mathrm{C}_{19: 1} \omega 12 t$ & & $1 \cdot 3$ & & & & \\
\hline $\mathrm{C}_{20: 1} \omega 7 c$ & $0 \cdot 48$ & & & & & \\
\hline $\mathrm{C}_{20: 1} \omega 9 t$ & & $0 \cdot 6$ & $0 \cdot 8$ & & & $1 \cdot 55$ \\
\hline $\mathrm{C}_{20: 2} \omega 6,9 c$ & & $0 \cdot 6$ & & & & \\
\hline iso- $\mathrm{C}_{15: 0}$ & & $1 \cdot 2$ & & & $0 \cdot 16$ & \\
\hline iso- $\mathrm{C}_{17: 0}$ & $1 \cdot 93$ & $1 \cdot 5$ & 1 & & $3 \cdot 34$ & \\
\hline \multicolumn{7}{|l|}{ Hydroxy fatty acids: } \\
\hline $\mathrm{C}_{12: 0} 3-\mathrm{OH}$ & & & $0 \cdot 3$ & & $0 \cdot 09$ & $0 \cdot 65$ \\
\hline iso- $\mathrm{C}_{13: 0} 3-\mathrm{OH}$ & & & & & $0 \cdot 27$ & \\
\hline iso- $\mathrm{C}_{15: 0} 3-\mathrm{OH}$ & $1 \cdot 86$ & $0 \cdot 5$ & & & & \\
\hline $\mathrm{C}_{16: 0} 3-\mathrm{OH}$ & & & & $5 \cdot 7$ & & \\
\hline $\mathrm{C}_{18: 0} 3-\mathrm{OH}$ & $0 \cdot 52$ & & & & & \\
\hline $\mathrm{C}_{18: 1} 2-\mathrm{OH}$ & & & & $5 \cdot 2$ & & \\
\hline \multicolumn{7}{|l|}{ Cyclopropane acids: } \\
\hline $\mathrm{C}_{17: 0}$ cyclo & & & $0 \cdot 5$ & & $0 \cdot 16$ & \\
\hline $\mathrm{C}_{19: 0} \omega 8 c$ cyclo & $9 \cdot 35$ & $25 \cdot 4$ & $13 \cdot 7$ & $4 \cdot 8$ & $12 \cdot 37$ & $3 \cdot 92$ \\
\hline \multicolumn{7}{|l|}{ Other: } \\
\hline 10-Methyl $\mathrm{C}_{19: 0}$ & & & & & $0 \cdot 16$ & $0 \cdot 4$ \\
\hline 11-Methyl $\mathrm{C}_{18: 1} \omega 8 c$ & & & & & $9 \cdot 99$ & \\
\hline Summed feature $2 \S$ & & & & $4 \cdot 7$ & & \\
\hline Summed feature 3 & $0 \cdot 56$ & $0 \cdot 4$ & $0 \cdot 5$ & $2 \cdot 3$ & $1 \cdot 42$ & \\
\hline Summed feature 5 & $0 \cdot 42$ & & & & & \\
\hline Summed feature 7 & & $43 \cdot 4$ & $46 \cdot 4$ & & $53 \cdot 22$ & $80 \cdot 48$ \\
\hline Unknown & 1 & $6 \cdot 7$ & $26 \cdot 4$ & & $0 \cdot 11$ & \\
\hline
\end{tabular}

${ }^{*}$ Mean values from eight strains, including the type strain.

$\dagger$ For unsaturated fatty acids, the position of the double bond is located by counting from the methyl $(\omega)$ end of the carbon chain. Isomers (cis and trans) are indicated by the suffixes $c$ and $t$, respectively.

¥This unsaturated fatty acid is also included in summed feature 7 .

\$Summed feature 2 comprises any combination of $\mathrm{C}_{12: 0}$ aldehyde, $\mathrm{C}_{14: 0} 3-\mathrm{OH}$ and/or iso- $\mathrm{C}_{16: 1}$. Summed feature 3 comprises any combination of iso- $\mathrm{C}_{15: 0} 2-\mathrm{OH}$ and/or $\mathrm{C}_{16: 1} \omega 7 \mathrm{c}$. Summed feature 5 comprises any combination of $\mathrm{C}_{18: 0}$ ANTE and/or $\mathrm{C}_{18: 2} \omega 6,9 c$. Summed feature 7 comprises any combination of $\mathrm{C}_{18: 1} \omega 7 c$, $\mathrm{C}_{18: 1} \omega 9 t$ and/or $\mathrm{C}_{18: 1} \omega 12 t$. 
to the genus Phyllobacterium, strain NL21 ${ }^{\mathrm{T}}$ has 17 -carbon fatty acids $\left(\mathrm{C}_{17: 0}, \mathrm{C}_{17: 1}\right.$, iso- $\mathrm{C}_{17: 0}$ and $\mathrm{C}_{17: 0}$ cyclo $)$ and different hydroxy fatty acids. Finally, it differs from the genus Defluvibacter in that it lacks the fatty acids $\mathrm{C}_{16: 1} \omega 7 \mathrm{c}$, $\mathrm{C}_{20: 1} \omega 7 c, \mathrm{C}_{12: 0} 3-\mathrm{OH}$ and 10-methyl $\mathrm{C}_{19: 0}$. Additional differences in fatty acid profiles are shown in Table 2.

DNA extraction was performed by dispersing colonies of strain $\mathrm{NL}_{2} 1^{\mathrm{T}}$ in $250 \mu \mathrm{l}$ TEN buffer $(50 \mathrm{mM}$ Tris/ $\mathrm{HCl}$, pH $8 \cdot 0 ; 10 \mathrm{mM}$ EDTA, pH $8 \cdot 0$; and $150 \mathrm{mM} \mathrm{NaCl}$ ) and then mixing them with $250 \mathrm{mg}$ sterilized $0 \cdot 4-0 \cdot 5 \mathrm{~mm}$ glass beads (B. Braun Melsungen). The DNA pellet was prepared as described by Labbé et al. (2003) and was then washed with $70 \%$ ethanol and resuspended in $50 \mu \mathrm{l}$ water.

The DNA G $+\mathrm{C}$ content of strain NL21 ${ }^{\mathrm{T}}$ was determined as described by Mesbah et al. (1989) by using two $15 \mathrm{~cm} \mathrm{C18}$ columns. $\lambda$-Phage DNA was used for calibration, whilst salmon sperm served as a control. The DNA G $+C$ content of strain $\mathrm{NL} 21^{\mathrm{T}}$ was lower than those of other characterized members of the family 'Phyllobacteriaceae' (57 vs 60-64 mol\%). The $16 \mathrm{~S}$ rDNA sequence of $\mathrm{NL}_{2} 1^{\mathrm{T}}$ was determined as reported previously (Labbé et al., 2003) (GenBank accession no. AF534573); both DNA strands of the resulting PCR product were sequenced.

Sequences were analysed by using BioEdit software, version 5.0.9.1 (http://www.mbio.ncsu.edu/bioedit/page2.html). Comparisons of bacterial sequences in gene databases were done with the BLASTN program (National Center for Biotechnology Information; http://www.ncbi.nlm.nih.gov/). The CLUSTALW 1.4 program (included in the BioEdit software package) was used to align sequences. Phylogenetic analyses were carried out with software applications from the PHYLIP package, version 3.5 (http://evolution.genetics. washington.edu/phylip.html). Bootstrap values (1000 replicates) were derived by using the SEQBOOT program. The DNADIST program was used to generate a distance matrix for each bootstrap replicate. Each number in the matrix represented the distance between a pair of sequences. The FITCH program was used to calculated a tree according to the Fitch-Margoliash algorithm. Lastly, the CONSENSE program was used to derive consensus trees. Strain designations and GenBank accession numbers for 16S rDNA sequences of reference strains are given in Fig. 1.

Representative members of the family 'Phyllobacteriaceae' showed 16S rDNA sequence similarity values of approximately $95 \%$ with strain $\mathrm{NL}^{2} 1^{\mathrm{T}}$. The closest species with validly published names to strain $\mathrm{NL} 21^{\mathrm{T}}$ were Mesorhizobium tianshanense and Mesorhizobium chacoense (95・1\%). However, phylogenetic analysis showed that strain $\mathrm{NL}_{2} 1^{\mathrm{T}}$ is not related closely to any genus within the family 'Phyllobacteriaceae' (Fig. 1). Parsimony and neighbour-joining analyses were also done with PHYLIP software (DNAPARS and NJ). These two methods produced phylogenetic trees that were similar to the consensus tree. Sequence similarity analysis also revealed that strain $\mathrm{NL}^{2} 1^{\mathrm{T}}$ shows $99 \cdot 8 \%$ similarity (only three different nucleotides) to strain TUT1018

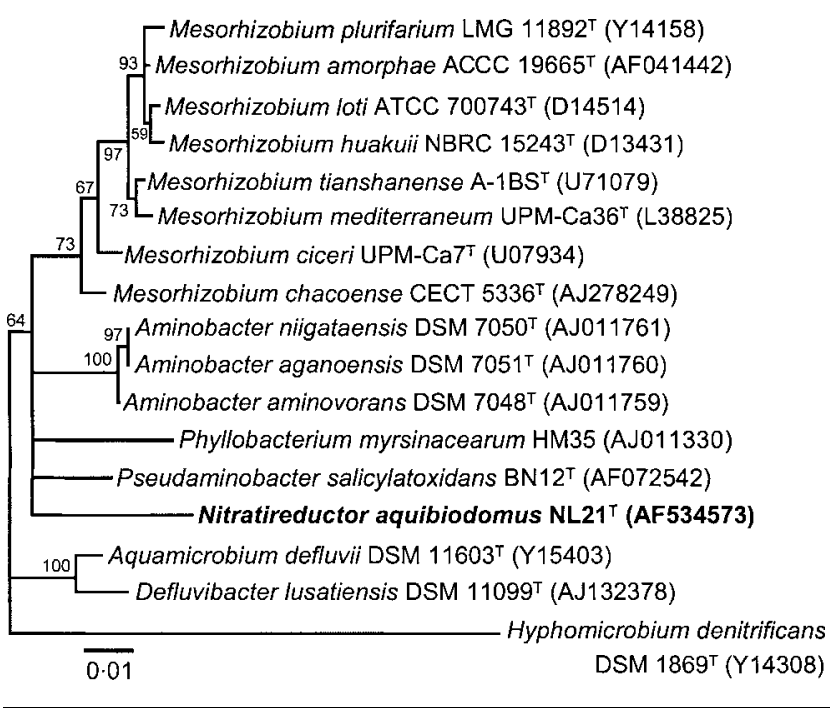

Fig. 1. Phylogenetic analysis of $16 \mathrm{~S}$ rDNA sequences. Evolutionary distances among $16 \mathrm{~S}$ rDNA of strain $\mathrm{NL}^{\top} 1^{\top}$ and all species of the family 'Phyllobacteriaceae' with validly published names are illustrated (Hyphomicrobium denitrificans was used as the outgroup species). The tree was inferred from a matrix of pairwise distances by using $1400 \mathrm{nt}$ (DNADIST). The FITCH program was used to derive the best phylogenetic tree for each replicate. Lastly, the CONSENSE program was used to derive the consensus tree. Numbers indicate percentages of 1000 bootstrap resamplings; only values $>50 \%$ are shown. Bar, 0.01 nucleotide substitution per site.

(GenBank accession no. AB098586), which was isolated from a biowaste sequence-batch composting system (Hiraishi et al., 2003).

\section{Description of Nitratireductor gen. nov.}

Nitratireductor (Ni.tra.ti.re.duc'tor. N.L. n. nitras nitrate; L. v. reducere to bring back, reduce; N.L. masc. n. Nitratireductor nitrate-reducing bacterium).

Gram-negative rods, $1 \mu \mathrm{m}$ in diameter and $2-3 \mu \mathrm{m}$ in length. Multiplies by budding. Cells are pleomorphic in rapid growth, motile and oxidase- and catalase-positive. Colonies on R2A agar are white, $2-3 \mathrm{~mm}$ in diameter, smooth, circular and convex. Optimum growth conditions are $30-35^{\circ} \mathrm{C}$ and $\mathrm{pH} 7-7 \cdot 5$. No growth occurs at $\mathrm{pHs}$ lower than 7. Major fatty acids are $\mathrm{C}_{18: 1} \omega 7 c(75 \%)$, $\mathrm{C}_{19: 0} \omega 8 c$ cyclo $(9 \cdot 4 \%)$ and $\mathrm{C}_{18: 0}(4 \cdot 2 \%)$. DNA G $+\mathrm{C}$ content is $57 \mathrm{~mol} \%$. Physiological characteristics are shown in Table 1. Phylogenetically, the genus is a member of the $\alpha$-subclass of the Proteobacteria. The type species is Nitratireductor aquibiodomus.

\section{Description of Nitratireductor aquibiodomus sp. nov.}

Nitratireductor aquibiodomus (a.qui.bi.o.do' mus. L. fem. $\mathrm{n}$. aqua water; N.L. fem. n. biodomus Biodome; N. L. gen. n. aquibiodomus of the water of the Montreal Biodome). 
Description is the same as that given for the genus. Cells can reduce nitrate to nitrite, but not nitrite to nitrogen gas. $\mathrm{NaCl}$ is not required for growth, but $1 \% \mathrm{NaCl}$ stimulates growth. Strain $\mathrm{NL}_{2} 1^{\mathrm{T}}$ grows at $0-50 \mathrm{~g} \mathrm{NaCl} \mathrm{l}^{-1}$. Physiological characteristics are shown in Table 1.

The type strain is $\mathrm{NL} 21^{\mathrm{T}}\left(=\mathrm{DSM} 15645^{\mathrm{T}}=\right.$ ATCC BAA$762^{\mathrm{T}}$ ). Isolated from the marine denitrification system of the Montreal Biodome, Canada.

\section{Acknowledgements}

This research was supported by a grant to R.V. from the Natural Sciences and Engineering Research Council of Canada, by funding from the Montreal Biodome and by a scholarship to N.L. from the INRS - Institut Armand-Frappier. We are grateful to Encarna Velázquez for providing Phyllobacterium myrsinacearum and to Serge Messier for fatty acid analysis. Brian Colwill kindly revised the English style and grammar of this paper.

\section{References}

Bambauer, A., Rainey, F. A., Stackebrandt, E. \& Winter, J. (1998). Characterization of Aquamicrobium defluvii gen. nov. sp. nov., a thiophene-2-carboxylate-metabolizing bacterium from activated sludge. Arch Microbiol 169, 293-302.

Chen, W., Wang, E., Wang, S., Li, Y., Chen, X. \& Li, Y. (1995). Characteristics of Rhizobium tianshanense sp. nov., a moderately and slowly growing root nodule bacterium isolated from an arid saline environment in Xinjiang, People's Republic of China. Int J Syst Bacteriol 45, 153-159.

Costa, C., Dijkema, C., Friedrich, M., García-Encina, P., FernándezPolanco, F. \& Stams, A. J. (2000). Denitrification with methane as electron donor in oxygen-limited bioreactors. Appl Microbiol Biotechnol 53, 754-762.

Duncan, K. E., Sublette, K. L., Rider, P. A., Stepp, A., Beitle, R. R., Conner, J. A. \& Kolhatkar, R. (2001). Analysis of a microbial community oxidizing inorganic sulfide and mercaptans. Biotechnol Prog 17, 768-774.

Fritsche, K., Auling, G., Andreesen, J. R. \& Lechner, U. (1999). Defluvibacter lusatiae gen. nov., sp. nov., a new chlorophenoldegrading member of the alpha-2 subgroup of proteobacteria. Syst Appl Microbiol 22, 197-204.

Gerhardt, P., Murray, R. G. E., Wood, W. A. \& Krieg, N. R. (1994). Methods for General and Molecular Bacteriology. Washington, DC: American Society for Microbiology.
Hiraishi, A., Narihiro, T. \& Yamanaka, Y. (2003). Microbial community dynamics during start-up operation of flowerpot-using fed-batch reactors for composting of household biowaste. Environ Microbiol 5, 765-776.

Jarvis, B. D. W., Van Berkum, P., Chen, W. X., Nour, S. M., Fernandez, M. P., Cleyet-Marel, J. C. \& Gillis, M. (1997). Transfer of Rhizobium loti, Rhizobium huakuii, Rhizobium ciceri, Rhizobium mediterraneum, and Rhizobium tianshanense to Mesorhizobium gen. nov. Int J Syst Bacteriol 47, 895-898.

Kämpfer, P., Müller, C., Mau, M., Neef, A., Auling, G., Busse, H.-J., Osborn, A. M. \& Stolz, A. (1999). Description of Pseudaminobacter gen. nov. with two new species, Pseudaminobacter salicylatoxidans sp. nov. and Pseudaminobacter defluvii sp. nov. Int J Syst Bacteriol 49, 887-897.

Knösel, D. H. (1984). Genus IV. Phyllobacterium (ex Knösel 1962) nom. rev. (Phyllobacterium Knösel 1962, 96). In Bergey's Manual of Systematic Bacteriology, vol. 1, pp. 254-256. Edited by N. R. Krieg \& J. G. Holt. Baltimore: Williams \& Wilkins.

Labbé, N., Juteau, P., Parent, S. \& Villemur, R. (2003). Bacterial diversity in a marine methanol-fed denitrification reactor at the Montreal Biodome, Canada. Microb Ecol 46, 12-21.

Lechner, U., Baumbach, R., Becker, D., Kitunen, V., Auling, G. \& Salkinoja-Salonen, M. (1995). Degradation of 4-chloro-2methylphenol by an activated sludge isolate and its taxonomic description. Biodegradation 6, 83-92.

Mergaert, J., Cnockaert, M. C. \& Swings, J. (2002). Phyllobacterium myrsinacearum (subjective synonym Phyllobacterium rubiacearum) emend. Int J Syst Evol Microbiol 52, 1821-1823.

Mesbah, M., Premachandran, U. \& Whitman, W. B. (1989). Precise measurement of the $\mathrm{G}+\mathrm{C}$ content of deoxyribonucleic acid by highperformance liquid chromatography. Int J Syst Bacteriol 39, 159-167.

Tighe, S. W., de Lajudie, P., Dipietro, K., Lindstrom, K., Nick, G. \& Jarvis, B. D. (2000). Analysis of cellular fatty acids and phenotypic relationships of Agrobacterium, Bradyrhizobium, Mesorhizobium, Rhizobium and Sinorhizobium species using the Sherlock Microbial Identification System. Int J Syst Evol Microbiol 50, 787-801.

Urakami, T., Araki, H., Oyanagi, H. Suzuki K. \& Komagata, K. (1992). Transfer of Pseudomonas aminovorans (den Dooren de Jong 1926) to Aminobacter gen. nov. as Aminobacter aminovorans comb. nov. and description of Aminobacter aganoensis sp. nov. and Aminobacter niigataensis sp. nov. Int J Syst Bacteriol 42, 84-92.

Velázquez, E., Igual, J. M., Willems, A. \& 9 other authors (2001). Mesorhizobium chacoense sp. nov., a novel species that nodulates Prosopis alba in the Chaco Arido region (Argentina). Int J Syst Evol Microbiol 51, 1011-1021.

Zumft, W. G. (1997). Cell biology and molecular basis of denitrification. Microbiol Mol Biol Rev 61, 533-616. 